\title{
GREEN FINANCE - AN EMERGING TREND IN INVESTMENT
}

\author{
DR. RESHMI R PRASAD ${ }^{1} \&$ SABU K NAIR ${ }^{2}$ \\ ${ }^{1}$ Associate Professor, Department of Commerce, All Saints' College, Thiruvananthapuram, Kerala, India \\ ${ }^{2}$ General Manager \& Head of Marketing, Kerala, Freshtohome.com, Cochin, Kerala, India
}

\begin{abstract}
As the waves of green movement are sweeping the world, green finance plays an important role in the achievement of sustainable development. Worldwide organisations are engaged in eco-friendly policies. Companies can be sustainable and green in multiple ways and employees are no exception to this. Promoting green finance helps to ensure that green investments are prioritised. Green investments are the investment activities that concentrate on projects committed towards the preservation of natural resources. Focus can be on greening the existing infrastructure spending or mobilising additional investments in key sectors. Green investment can also be made in companies that operate in other business areas, but focus additionally on green initiatives. Branding is not sufficient to confirm commitment to green initiatives. Every investor should undertake a detailed study to ensure that a company adheres to the standards set by regulatory and governance bodies. It is a threat to the existence of the planet which made the business community aware of their responsibility for implementing policies that are ecofriendly. This in turn enables them to attract capital from investors who wish to make a tangible impact with their investment. The present study focuses on identifying the various investment opportunities and challenges faced by the green investment companies, identifying leading Indian companies working in accordance with the green protocol, identify the green finance instruments, and also how companies investing in green initiatives can raise funds for the same. The study is carried out using secondary data collected from books, websites, and journals.
\end{abstract}

KEYWORDS: Green finance, Environment Friendly, Green Movement, Sustainability, Green Protocol

Received: Jun 08, 2020; Accepted: Jun 28, 2020; Published: Sep 15, 2020; Paper Id.: IJMPERDJUN20201241

\section{INTRODUCTION}

Financing for the benefit of the climate and environment is the essence of green finance. Green and finance, which may not be an imaginable mix twenty years ago, it has become the new trend in the financial industry nowadays. The way to sustainable growth and development is by "greening" the economy. This can be achieved through introducing green financial products, Environmental, Social, and Corporate Governance (ESG) disclosure, Task Force on Climate-related Financial Disclosures (TCFD) recommendations, environment disclosure by enterprises and by responsible investment (Figure 1.).This transition necessitates huge investment in the green sectors. UNEP estimated, the annual investment for a green economy as 2\% of the global GDP for the period between 2010 and 2050. The need of today's population can be satisfied by greening the global economic growth. Developing countries play a vital role in increasing green investment. The World Bank Report states that the world is on the track for an average global temperature increase of $4^{\circ}$ Celsius above preindustrial levels, bringing about extreme heat waves, hurricanes, and life-threatening rise in sea levels. Moreover, with the depletion in critical resources, there is no corresponding increase in the production of natural resources. The urge to go green is a recent experience for many companies. Investment managers have started categorising firms by the position they occupy 
in the green spectrum. Whenever a green investment catches the eyes, there are innumerable ways by which it can be included in the portfolio. Mutual funds, stocks, bonds, and even money market funds focusing on the environment are available. Green investment is a shift in the global economy's transition to sustainability.

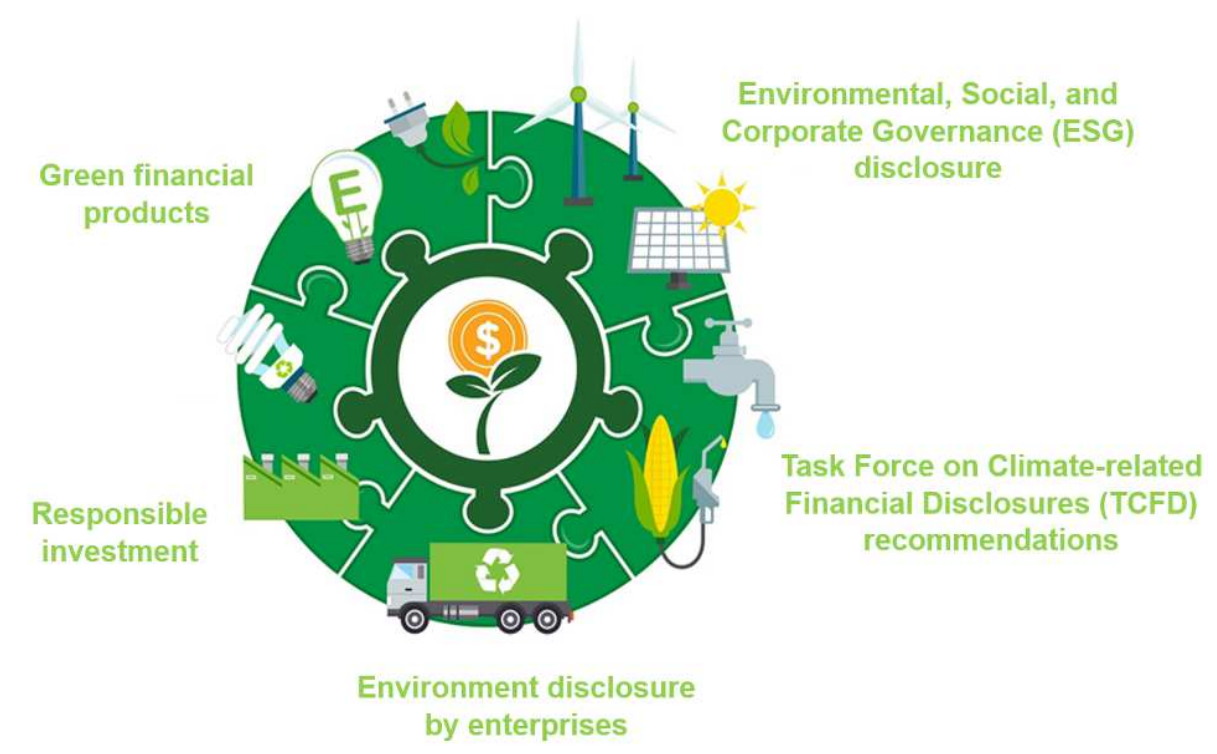

Figure 1: Developing the Green (Source: IFEC).

\section{SIGNIFICANCE OF THE STUDY}

Investments made in activities leading to the promotion of environmentally friendly business practices and preservation of natural resources are termed Green investments. As support from consumers and investors keep increasing day by day, it is expected that the entrepreneurs will increasingly enter the green industry in the years to come. The start-up green companies strive for three things - (a) generate revenue and profit for the shareholders, (b) work to increase social benefit, and (c) reduce environmental issues. Numerous investment avenues are available in the so-called green or clean sector which provides excellent investment opportunities for green investors. Unfortunately, the investors face a dual-fold challenge - increase personal wealth on the one side, and, on the other to make the world a better place through socially responsible investment.As the business world has awakened to the concept of green, an investor should blend his financial commitment, risk tolerance and goals, environmental goals and sustainable practices before making any investment.

\section{REVIEW OF LITERATURE}

Martin and Moser [2016], in their study, revealed that manager's green investment has no impact on future cash flows, but investors respond favorably when managers make an investment and highlight the societal benefits rather than the cost to the company. The study highlighted that managers value the societal benefits even though the cost exceeds the benefit from the investors' reaction. The findings of the study point out that investors and managers trade off wealth for societal benefits and also explain the manager's CSR disclosures. Miller et. al., [2008] in their study revealed that the payoff from a wise green investment is easy to justify even if it is based on purely profit motivations. Morot et. al., [2012], in their study, advances a green investment policy framework, taking infrastructure investment as a starting point and looking only at climate change mitigation and adaptation. The study highlighted the significant opportunities and challenges that exist today in both developed and developing countries in transition to LCR development through investment in both renovated 
and new infrastructures. The study concludes by suggesting that it is possible to generate multiple local development benefits from LCR infrastructure investment. Eyraud et. al., [2013] fill the gap in the macroeconomic literature on renewable sources of energy. The study points out that policy interventions like the introduction of carbon pricing schemes, which require the use of green energy, have a positive and significant impact on green investment.

\section{OBJECTIVES}

The study focuses on: -

- Identifying the investment opportunities and challenges faced by the green investment companies.

- Identifying leading Indian Companies working as per Green Protocol.

- Understanding the green finance instruments and how the companies investing in Green raise funds for the same.

\section{METHODOLOGY}

This article presents a survey of secondary data from books, journals, articles, and web resources on the challenges and opportunities in the field of Green Investment.

\section{DISCUSSIONS}

Starting with the different forms of renewable energy, there exist a range of green investment opportunities:

\section{Green Power Investment}

There exist ample investment opportunities in hydropower, solar, wind, geothermal, and biomass rather than on industries based on fossil fuels. According to the report of the Indian Renewable Energy Industry (October 2019) the Indian Renewable Energy Sector is the fourth most attractive renewable energy market in the world. As of October 2018, India ranked 5th in the world for the capacity of installed renewable energy. India ranked second among the emerging economies to lead to the transition to clean energy, according to the 2018 Climate Scope Report. The power generation reached 107.22 billion units between April 2018 to January 2019.

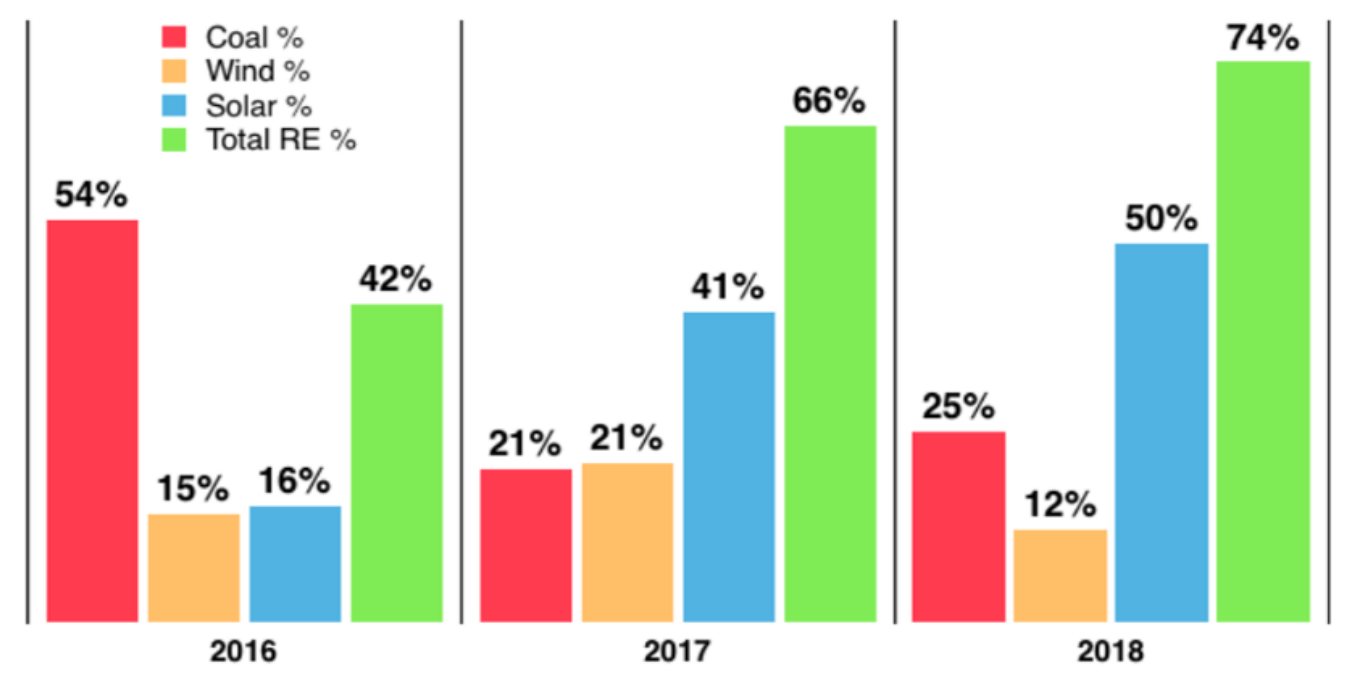

(Source: CleanTechnica)

Figure 2: Rising Trend of Renewable Energy in India. 


\section{Hydropower Projects}

Hydropower projects are important drivers of sustainable energy. As the population continues to grow, we are sure to run out of clean water very fast. Companies that collect, clean, and distribute water can be good targets for green investment. Mutual funds provide ways to invest in diverse water-related technologies and industries. The Calvert Global Water Fund and the Allianz GL Global water fund multiple companies that boost tap water supply in countries across the globe. According to the International Renewable Energy Agency, water is the world's number one renewal energy source. Thus, ample opportunities exist for investment in hydropower as it encompasses diverse technological and infrastructure growth in many dimensions.

\section{Wind Power}

Apart from the generation and sale of power, wind power business includes the design and construction of wind turbines as well. Opportunities exist for making investment in companies that produce and sell wind-generated energy and in companies that produce wind turbine technology.

\section{Solar Power}

The future looks bright for the solar energy industry as it can power a wide range of machines and gadgets and companies that produce solar energy panels are a rich field for green investment. Apart from the manufacture and sale of solar energy panels, investment opportunities also exist in its installation and on-going maintenance. Solar focussed companies come from divergent sectors and even the major mainstream utilities and energy companies promote solar energy as options to their consumers. Leading producers of solar panels include First Solar, JinkoSolar Holding company Ltd, and Sunpower Corp.

\section{Green Transportation}

The current transportation system is beset with numerous problems including but not limited to global warming, environmental degradation, and emission of greenhouse gases. Studies reveal that $23 \%$ of the globe's greenhouse gas emission results from the combustion of fossil fuels. Thus, transportation contributes heavily to greenhouse gas emissions. The solution to this is the greening of the transportation sector, whereby investments are channelled towards transportation practices that are eco-friendly and have zero or minimal impact on the environment. Diverse investment opportunities exist in the innovation and production of vehicles that use renewable energy sources rather than diminishing natural resources. Ballard Power Systems is the leading producer of power cells that can be used in cars and power plants. Modern time has witnessed significant advancements in researches aimed at developing alternative power sources for automobiles.

\section{Waste Reduction}

Waste minimization helps in the promotion of a sustainable society. Investments can be made in business enterprises aiming at recycling and waste management. The Allied Waste Industries and Waste Management Companies are the leading companies with a large base of recycling facilities. Another promising approach to waste management has been demonstrated by Covanta Holding Company, where power is generated from the incineration of waste materials.

\section{Organics}

Apart from sustainable farming practices, organics include animal farming practices without the use of growth hormones. Ample investment opportunities exist in big organic food companies. The biggest organic food companies include Whole Foods Market, United Nations Food, and NBTY. 


\section{Aquaculture Industry}

Another food-related investment opportunity is sustainable fish farming. According to the Food and Agriculture Organization of the United Nations, $31.4 \%$ of global fisheries are operated at biologically unsustainable levels. Investment in the aquaculture industry offers a huge opportunity. Sustainable fish farming ensures that the fish population does not decline due to fishing practices. The Marine Harvest ASA, a Norwegian firm is the leading industry in this field.

\section{Geothermal Energy}

This can be used for heating, cooling, and generation of electricity. In some countries, it has been used for cooking as well. Geothermal power plants can diversify the weather risks of other renewable energy as they use the earth's natural heat to generate electricity. Geothermal energy companies offer huge investment opportunities for green investors. Moreover, an investment can also be made in drilling companies. The top geothermal industries include Calpine Corp, Ormat Technologies Inc. and US Thermal Inc.

\section{Pollution Control}

The pollution control industry comprises of companies that enforce the governance and regulation of mandatory legislation on the emission of chemicals harmful to the environment. Pollution control industries and technologies are fertile areas of green investments. The leading companies which develop pollution control techniques include Fuel Tech Versar, Market Vectors Environmental Services ETF, and Invesco Cleantech.

\section{CHALLENGES}

Mobilizing capital for green investment has been limited by several microeconomic challenges including problems in internalizing environmental externalities, and lack of clarity in the definition of green initiatives. In India, renewable energy programs have been led by the private sector. Despite the efforts made to get support from the World Bank, getting Green finance is not easy. India is making every effort to open Green windows through IREDA for assistance to sectors not catered by other financial institutions.

\section{Leading Indian Companies Committed to Green Protocol}

Green Protocol refers to all those measures, which when adopted, results in a significant reduction in waste through the deployment of reusable alternatives for disposables. In the "National Games, 2015" Green Protocol was implemented as a major event. The entire utilities of the games were planned to focus on the prevention of waste generation. Today, in Kerala, Green Protocol is toddling in various arena. Kerala Raj Bhavan implemented a number of initiatives under the the 'Go Green' initiative including an organic vegetable garden and a medicinal plant garden and is considered a model in handling waste. As a part of Prime Minister's Swatch Bharath Mission, a biodegradable waste plant was established, and it is expected that Kerala Raj Bhavan would become an eco-friendly campus in a short time.

Pratibha Sharma, the former National Coordinator of Global Alliance for Incinerator Alternatives (GAIA) India said that corporations have to take express steps to contain environmental pollution, and proactively take responsible actions to remedy the effects of environmental the pollution they contributed to in the past. She said that the Government should enact producer responsibility policy prohibiting corporations from ignoring the need for protecting the environment.

India's largest renewable companies, according to the "Clean Energy Investment Trends 2019" reports include Acme Solar, Adani and Greenko Holdings at the top of the list of India's largest solar power producers by capacity. These 
are followed by Azure Power, Tata Power, Renew Power, NTPC, Avaada Power, Hero Future Energies and NLC.In the wind energy the sector, Renew Power, Greenko Energy Holdings and Sembcrop top the charts according to data by the International Energy Agency and CEEW, followed by Tata Power, Mytrah Energy, CLP, Hero Future Energy, Inox Renewables, and Torrent Power. Reports indicate that ambitious targets, supportive policy, and falling technology costs improved the attractiveness of financing utility-scale solar PV and wind projects. They further point to the fact that $75 \%$ to $80 \%$ of the wind energy equipment is being made in India and India holds the potential to be a huge market in this area. The wind energy export of the country is around $\$ 500$ billion per annum. The Secretary-General of Indian Wind Turbine Manufacturers Association has forwarded a recommendation to the Indian government to increase the export incentive from $2 \%$ to $5 \%$ so as to boost the export to trillions within 2 years.

To improve green transportation, a new scheme named "Green Urban Transport Scheme" has been launched by the Ministry of Urban Development with the intention of developing and improving the climate-friendly transportation system. The leading players in theorganic food industry in India include the Rajasthan-based Nature Land Organic Food and the Nagpur-based "My Green Mart" Apart from food products they also produce a variety of certified organic bed sheets. The third in this category include Samrudhi Organic Farm based in Pune. According to the UNICEF (2013) report, access to safe drinking water is a challenge in rural areas. A huge business potential exists in this sector. At present, there are seven firms investing in this sector - Aavishkaar, Acumen, Avantage Venture, Khosla Impact Fund, LGTVP, Matrix Partners, and The Sandi Group.

\section{Green Finance Instruments and Fund Raising by Companies}

The predominant financial instrument in green financing is debt and equity. Of this, equity finance is used in the early stages of developing a project while debt financing is used in the later stages of development in combination with equity. Green funds can be raised by private equity firms, corporations, hedge funds, and even individuals. Different options are available to corporations like crowdfunding, an angel investor, venture capital, and so on. The green investment option available to an investor include securities, electronically traded funds, mutual funds, and bonds. These can be offered even by the government to generate revenue either to fund its own projects or the entire business.

The first-ever green bond issued by a technology company was the one issued by Apple Company worth $\$ 1.5$ billion. This bond won the award by the Environmental Finance in 2016. Another bond which gained popularity was the Sustainability Bond issued by Starbucks with the motive of boosting sustainable agriculture.

\section{CONCLUSIONS}

Individual perceptions of the concept of "green investments" vary. Some investors prefer pure-play options, while others are interested in investing in companies that use natural resources and manage waste but draw their revenue from multiple sources. Compared to other equity strategies, investing in a green company is risky as most of the companies in this arena are in the development stage with low revenue. There is risk associated with an investment in any technology and green investment is no exception. Investing in different green sectors and thereby diversifying the portfolio is a good investment strategy. Managed exchange-traded funds and mutual funds are good investment options. Before making an investment, every investor should make sure that he is not trapped in the "green washing trap", a situation in which a company claims to be green but is actually not. 
The expenses of greening will be high, but, in the long run, not doing so will be more expensive. To accelerate green growth, the government, investors, and international organisations should make every effort to overcome the barriers. The private investors should take a new approach to benefit from green investment opportunities. They should not wait for public policies to mitigate the risk but make greater use of investor forums and engage with public finance agencies to advance new financing solutions, thereby opening up a sustainable market, as the only route to sustained growth and development is by greening the economy.

\section{REFERENCES}

1. Martin, P. R., \& Moser, D. V. (2016). Managers' green investment disclosures and investors' reaction. Journal of Accounting and Economics, 61(1), 239-254.

2. Miller, N., Spivey, J., \&Florance, A. (2008). Does green pay off? Journal of Real Estate Portfolio Management, 14(4), 385400.

3. Corfee-Morlot, J., Marchal, V., Kauffmann, C., Kennedy, C., Stewart, F., Kaminker, C., \& Ang, G. (2012). Towards a green investment policy framework: The case of low-carbon, climate-resilient infrastructure.

4. Eyraud, L., Clements, B., \& Wane, A. (2013). Green investment: Trends and determinants. Energy Policy, 60, 852-865.

5. Diesendorf, M. (2001). Models of sustainability and sustainable development. International Journal of Agricultural Resources, Governance and Ecology, 1(2), 109-123.

6. Bhoganadam, S., Rao, D. N., \&Dasaraju, S. (2017). A study on Issues and Challenges faced by SMEs: A Literature Review. Research Journal of Sri S. Ramasamy Naidu Memorial College, 1, 48-57.

7. Geiger, P., Cajias, M., \&Fuerst, F. (2014). A Class of its Own? The Role of Sustainable Real Estate in a Conditional Value at Risk Multi-Asset Portfolio.

8. On World Environment Day, green groups in India tell corporations: Stop causing plastic pollution (2018), Retrieved from https://www.cag.org.in

9. James M. (2019), Top Green Investing Opportunities, Retrieved from https://www.investopedia.com

10. Arjun,D., Lucila, A., Barath, M.,(2019),Clean Energy Investment Trends 2019,Retrieved from https://www.ceew.in

11. Green Investing (2013), Retrieved from https://reports.weforum.org

12. Climate Action (2014), Retrieved from https://worldbank.org

13. Shoshanna, D. (2019), The 10 Fastest Growing Green Startups in 2019, Retrieved from https://www.investopedia.com

14. All about green(2019),Retrieved from https://www.ifec.org.hk

15. Mridul,C.(2019), 74\% Of India's New Power Capacity Addition In 2018 Was Renewables, Retrieved from https://cleantechnica.com

16. Indian Renewable Energy Industry Analysis(2020), Retrieved from https://www.ibef.org 
